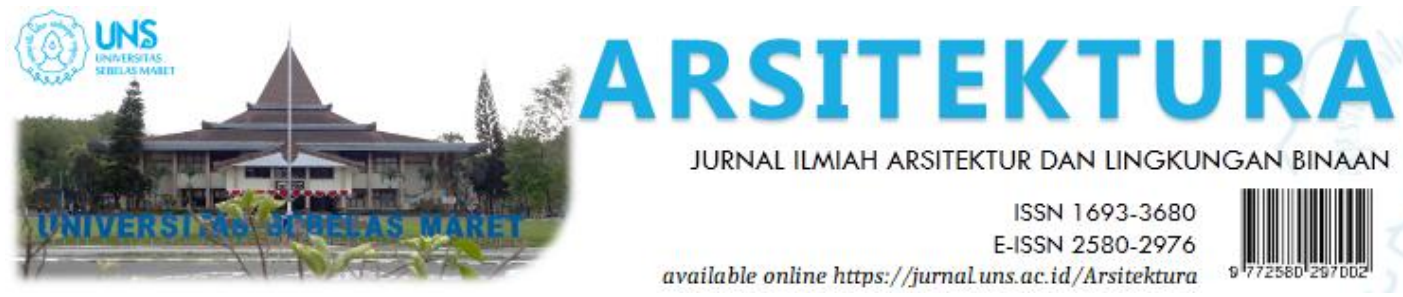

Volume 17 Issue 2 October 2019, pages:177-184

\title{
Penerapan Konsep Healing Environment pada Strategi Perancangan Pusat Pelayanan Lanjut Usia di Surakarta
}

\section{The Implementation of Healing Environment Concept in Elderly Care Center Design Strategy in Surakarta}

\author{
Mintari Nur Aziza ${ }^{1 *}$, Hari Yuliarso ${ }^{2}$, Hardiyati ${ }^{3}$ \\ Program Studi Arsitektur, Fakultas Teknik, Universitas Sebelas Maret Surakarta ${ }^{1}$ \\ Email : mintarinaziza@gmail.com * \\ Program Studi Arsitektur, Fakultas Teknik, Universitas Sebelas Maret Surakarta ${ }^{2}$ \\ Program Studi Arsitektur, Fakultas Teknik, Universitas Sebelas Maret Surakarta ${ }^{3}$
}

DOI: https://doi.org/10.20961/arst.v17i2.24358

Received: October 1, 2018 Revised: October 12, 2018 Accepted: March 30, 2019 Available online:October 31,2019

\begin{abstract}
When entering the elderly phase, humans will experience a physical and psychological conditions declined, this causes the elderly to need special and different services compared to normal adults. In order to overcome these problems, also to reach Surakarta as an Elderly Friendly City, a Elderly Care Center is needed as a place that provides various services needed by the elderly. This care center requires a healing environment concept that can create a conducive environment so that it can restore and improve physical and psychological health conditions of the elderly. In order to achieve healing environment, there are some approaches that can be done, such as the sensory approach (sense of sight, sense of touch, sense of hear, and sense of smell), natural approach (healing garden), and psychological approach. The method that used are observational studies to the community, field studies, and literature studies on related theories. The approaches og healing environment concept can be applied in the analysis of planning and design, so that will result the Eldelry Care Center with an environment where the elderly can easily adapt, feel comfortable, safe, and can support the recovery and improvement of the physical and psychological conditions of the elderly.
\end{abstract}

Keywords: elderly, care center, healing environment

\section{PENDAHULUAN}

Lanjut usia merupakan bagian dari proses kehidupan manusia. Pada dasarnya, setiap manusia akan melewati fase lanjut usia dalam kehidupannya setelah melewati fase kanakkanak, fase remaja, dan fase dewasa. Pada fase lanjut usia tubuh manusia akan secara perlahan mengalami penurunan fungsi. Ketika itulah manusia mulai memasuki proses penuaan (Maryam dkk, 2008).
Jumlah lanjut usia di Indonesia semakin meningkat tiap tahunnya. Tercatat pada tahun 2016 Indonesia memiliki 22,5 juta penduduk lanjut usia, atau setara dengan $8,72 \%$ dari seluruh total penduduk di Indonesia (Badan Pusat Statistik Indonesia, 2017). Angka ini menempatkan Indonesia sebagai negara dengan penduduk lanjut usia terbanyak ke-4 di dunia. Semakin meningkatnya jumlah lanjut usia mengakibatkan semakin meningkat pula masalah yang terjadi pada penduduk lansia. 
Masalah utama yang dimiliki penduduk lanjut usia di Indonesia di antaranya adalah masalah kesehatan dan ekonomi. Sebanyak 49,77\% dari penduduk lansia mengalami keluhan sakit (Badan Pusat Statistik Indonesia, 2017). Hal ini dikarenakan ketika memasuki fase lanjut usia, manusia akan mengalami penurunan kondisi fisik dan fungsi organ tubuh, serta penurunan kondisi psikologis. Sebagian lansia masih harus bekerja meski tidak sedikit dari mereka yang sudah mengalami penurunan kondisi fisik guna memenuhi kebutuhan sehari-hari. Kedua masalah ini dapat diatasi dengan perbaikan pelayanan kesehatan bagi lansia dan pemberian pembinaan bagi lansia agar dapat membuka usaha sederhana, sehingga para lansia tetap dapat mendapatkan penghasilan tanpa teralu menguras energi.

Kota Surakarta sendiri memiliki jumlah lansia yang cukup tinggi pula yakni sebanyak 54.564 jiwa, setara dengan 10,6\% dari total seluruh penduduk Kota Surakarta. Ini berarti, presentase penduduk lansia di Kota Surakarta lebih tinggi dibanding presentase nasional. Hal ini dapat terjadi karena, salah satunya, dipengaruhi oleh semakin meningkatnya usia harapan hidup di kota ini. Usia harapan hidup Kota Surakarta sudah mencapai 72 tahun dibanding usia harapan hidup nasional yang hanya mencapai 70,7 tahun. Hal ini menjadi salah satu pendorong Kota Solo dijadikan studi asesmen untuk menjadi Kota Ramah Lanjut Usia 2030 bersama 14 kota lainnya di Indonesia.

Kota Surakarta sebagai Kota Ramah Lanjut Usia 2030, perlu ditingkatkan kesadaran akan pentingnya pelayanan bagi lanjut usia, yakni dengan perancangan Pusat Pelayanan Lanjut Usia. Pusat Pelayanan Lanjut Usia yang direncanakan bertujuan sebagai suatu tempat yang menyediakan pelayanan bagi para lanjut usia untuk memenuhi segala haknya menikmati masa tua dengan lebih baik. Pelayanan yang diberikan meliputi pelayanan kesehatan berupa klinik khusus lanjut usia, pelayanan hunian yang ditujukan bagi lanjut usia terlantar dan lanjut usia yang kondisinya tidak memungkinkan untuk melanjutkan hidup di rumah masing-masing, serta pelayanan pembinaan ketrampilan, pembinaan psikologis, dan pembinaan spiritual bagi lanjut usia secara umum di Kota Surakarta. Namun, pada saat ini fasilitas pelayanan bagi lansia di Kota Surakarta dinilai masih kurang. Kondisi fisik bangunan dan lingkungan pada panti wredha di Kota Surakarta kurang mendukung dan mengakomodasi kebutuhan dari lansia untuk menjalani kehidupan yang sehat. Seperti yang terjadi di Panti Wredha di wilayah Surakarta. Berdasarkan pengamatan di lapangan oleh penulis, pada Panti Wredha Dharma Bakti mayoritas lansia merasa jenuh dan hanya menghabiskan waktu dengan mengobrol dan melamun di depan area kamar. Begitu pula lansia di Panti Jompo Aisyiah dimana panti jompo ini tidak memiliki ruang terbuka sama sekali dan lansia sangat jarang keluar panti. Hal ini mengakibatkan lansia kurang terpapar sinar matahari dan mengakibatkan kurang sehat.

Faktor lingkungan memegang peran besar dalam proses penyembuhan manusia yaitu sebesar $40 \%$, faktor medis $10 \%$, faktor genetis $20 \%$ dan faktor lain-lain 30\% (Jones, 2003 dalam Kurniawati, 2011).

Untuk itu dalam perancangan Pusat Pelayanan Lanjut Usia ini akan dimunculkan konsep healing environment dimana merupakan kombinasi interaksi antara fisik bangunan dan memperhatikan efek psikologis pengguna sehingga dapat membentuk sebuah lingkungan yang dapat meningkatkan kesejahteraan fisik dan mental dari pengguna (Clegg, 1987 dalam Stoneham dan Thoday, 1996).

\subsection{Healing Environment}

Healing environment merupakan lingkungan fisik pada bangunan pelayanan kesehatan dimana dapat mempercepat waktu pemulihan kesehatan pasien atau mempercepat proses adaptasi pasien dari kondisi kronis serta akut dengan melibatkan efek psikologis pasien di dalamnya (Stichler, 2001 dalam Dijkstra, 2009). Healing environment tidak hanya bagi orang sakit, namun dapat pula diterapkan salah satunya di panti lanjut usia, sebagai aspek pendorong pemulihan psikologis pada lanjut usia. Kesehatan bagi usia lanjut merupakan gabungan akumulasi dari penyakit dan kebiasaan dalam hidup sehat sepanjang masa hidupnya (Tsao dalam Stamenovic, 2009). Sehingga sangat penting untuk menjaga kesehatan baik kesehatan fisik maupun psiklogis bagi lanjut usia. 
Menurut Murphy (2008) dalam (Lidyana dkk, 2013), terdapat tiga pendekatan yang digunakan dalam mendesain healing environment, yaitu alam, indra dan psikologis. Pendekatan alam memberi efek restoratif yang besar bagi kesehatan, seperti menurunkan tekanan darah, memberikan konstribusi bagi keadaan emosi yang positif, menurunkan kadar hormon stress dan meningkatkan energi. Pendekatan alam ini dapat berupa healing garden yang dimunculkan dalam bangunan serta pemberian bukaan dalam tiap ruangruang sehingga dapat menjadi penghubung antara ruang dalam dan ruang luar.

Pendekatan indera pada manusia meliputi pendengaran, pengelihatan, peraba dan penciuman serta perasa. Masing-masing dari kelima indera ini memegang peran penting dalam proses penyembuhan (healing). Indera pendengaran berupa suara yang menyenangkan dan menenangkan dapat mengurangi tekanan darah dan detak jantung, sehingga menimbulkan sebuah suasana yang kemudian mempengaruhi sistem saraf. Beberapa suara yang dapat menenangkan pikiran, yaitu suara musik, suara air mancur, dan suara di alam. Kemudian indera pengelihatan dapat mempengaruhi perasaan seseorang. Pemandangan alam, cahaya matahari, karya seni dan warna-warna tertentu dapat membuat mata menjadi santai. Indera peraba atau sentuhan merupakan mekanisme dasar dalam menjelajahi dunia selama masa kanak-kanak karena sentuhan menegaskan apa yang mereka lihat, cium, rasa dan dengar. Pada indera penciuman, bau yang menyenangkan dapat menurunkan tekanan darah dan detak jantung.. Selanjutnya, indra perasa menjadi terganggu pada saat pasien mengalami sakit ataupun menerima pengobatan. Penggunaan tekstur dapat mempengaruhi stimulasi indera peraba.

Secara psikologis, healing environment membantu proses pemulihan pasien menjadi lebih cepat, mengurangi rasa sakit dan stress. Perawatan pasien yang diberikan memperhatikan terhadap pilihan, kebutuhan dan nilai-nilai yang menuntun pada keputusan klinis pasien. Ada enam dimensi untuk perawatan pasien, antara lain rasa kasih sayang, empati dan tanggapan terhadap kebutuhan, koordinasi dan integrasi, informasi dan komunikasi, kenyaman fisik, dukungan emosional, keterlibatan keluarga dan temanteman (Departement of Health, 2001 dalam Lidayana dkk, 2013).

Diharapkan dengan penerapan healing environment para pengguna baik itu lanjut usia, keluarga yang mengunjungi, maupun karyawan dan pengelola dapat merasa nyaman, mudah beradaptasi, dan dapat mendukung proses pemulihan fisik dan psikis bagi lanjut usia sehingga tidak merasa tertekan ataupun stress ketika berada di Pusat Pelayanan Lanjut Usia ini. Konsep ini dinilai sangat penting karena kondisi lingkungan akan sangat mempengaruhi kondisi dari lanjut usia yang pada umumnya telah menngalami penurunan kondisi fisik dan psikis.

\section{METODE}

Metode dalam perencanaan dan perancangan Pusat Pelayanan Lanjut Usia ini, diawali dengan konstruksi gagasan masalah yang dilatarbelakangi fenomena yang terjadi pada lanjut usia khususnya di Kota Surakarta yang menghasilkan obyek rancang berupa Pusat Pelayanan Lanjut Usia. Kemudian dilakukan pengumpulan data yang menjadi bahan pertimbangan dalam analisis data untuk mendapatkan keputuhan desain pada bangunan. Pengumpulan data didapatkan melalui wawancara, observasi, studi literatur, dan data empiris. Analisis data dilakukan berdasarkan penerapan strategi desain dari konsep healing environment yang digunakan sebagai dasar untuk mensintesa aspek fisik dan non fisik yang akan menghasilkan kriteria desain dalam perencanaan dan perancangan Pusat Pelayanan Lanjut Usia.

Penerapan konsep healing environment pada bangunan berpengaruh pada komponenkomponen pembentuk lingkungan, di antaranya adalah persoalan peruangan, persoalan pemilihan lokasi, persoalan pengolahan tapak, serta persoalan bentuk dan tampilan pada eksterior dan interior.

Dalam penerapan konsep healing environment pada komponen diatas, terdapat tiga pendekatan yang dapat dilakukan dalam mendesain healing environment, yakni pendekatan indera, pendekatan alam, dan pendekatan psikologi. Pendekatan indera 
mencakup indera penglihatan, indera pendengaran, indera peraba, dan indera penciuman. Pendekatan alam berupa penataan landscape dan healing garden. Kemudian pendekatan psikologi menekankan pada kenyamanan dan keamanan bagi penghuni khususnya lanjut usia.

\section{HASIL DAN PEMBAHASAN}

\subsection{Persoalan Peruangan}

Kebutuhan ruang pada Pusat Pelayanan Lanjut Usia didasari pada pengguna, aktifitas yang terjadi dalam pusat pelayanan ini yang akan membentuk pola perilaku pengguna. Pola Perilaku pengguna juga dipengaruhi oleh rangsangan-rangsangan diterima dari lingkungan (Zhafran dkk, 2017). Pendekatan konsep healing environment yang digunakan dalam analisis peruangan ini adalah pendekatan psikologis dimana mengutamakan kenyamanan lanjut usia dalam pemenuhan kebutuhan ruang yang sesuai standar lanjut usia dan kemudahan serta keamanan sirkulasi antar ruang bagi lanjut usia.

Berdasarkan pertimbangan di atas, Pusat Pelayanan Lanjut Usia dibagi menjadi beberapa kelompok area kegiatan, yakni area penerimaan yang terdiri dari ruang lobby, resepsionis, dan ruang tamu; area hunian yang terdiri dari kamar tidur, kamar mandi, ruang santai, dan ruang makan; area klinik yang terdiri dari ruang tunggu, ruang periksa, apotek, ruang konsultasi psikologi, dan ruang fisioterapi; area penunjang pelayanan yang terdiri dari aula, fitness center, ruang workshop seni, galeri, ruang jahit dan rajut, ruang musik, ruang masak, perpustakaan, dan healing garden; area pengelola yang merupakan kantor bagi pengelola, perawat, dan ruang rapat; serta area service yang berisi ruang-ruang service dan utilitas.

\subsection{Persoalan Pemilihan Lokasi}

Pemilihan lokasi menjadi hal yang penting dalam perancangan Pusat Pelayanan Lanjut Usia ini karena lokasi yang dipilih harus memenuhi standar dan kriteria tertentu yang sesuai bagi lanjut usia. Pendekatan dalam konsep healing environment yang digunakan adalah pendekatan psikologis dimana dalam pemilihan lokasi Pusat Pelayanan Lanjut Usia dasar pertimbangannya adalah kenyamanan pengguna baik dari segi aksesibilitas, kondisi kontur, dan kenyamanan termal pada tapak. Kriteria pemilihan lokasi berdasarkan konsep healing environment antara lain dari segi aksesibilitas, tapak mudah dijangkau baik dengan kendaraan pribadi maupun kendaraan umum, tapak berada di lokasi strategis serta mudah menjangkau fasilitas umum seperti rumah sakit, lokasi tapak berada di kawasan dengan kontur yang relatif datar dan rata untuk memudahkan aksesibilitas lanjut usia di dalam tapak, lokasi tapak tidak bersebelahan langsung dengan sekolah, mall, maupun pasar sehingga tidak terlalu bising dan lalu lintas di depan tapak tidak terlalu padat, lokasi tapak tidak berada di kawasan industrial sehingga tidak rentan terkena polusi udara, air tercemar, maupun terkena gangguan akibat suara bising dari kawasan industri.

Berdasarkan kriteria diatas, lokasi yang paling sesuai untuk Pusat Pelayanan Lanjut Usia adalah Lokasi yang berada di wilayah Kerten, Surakarta tepatnya di Jalan Siwalan. Tapak yang tersedia memiliki luas $\pm 11.569 \mathrm{~m}^{2}$ dengan KBD sebesar $60 \%$. Kondisi eksisting tapak terpilih beserta ukuran dan batas-batas tapak dapat dilihat pada Gambar 1.

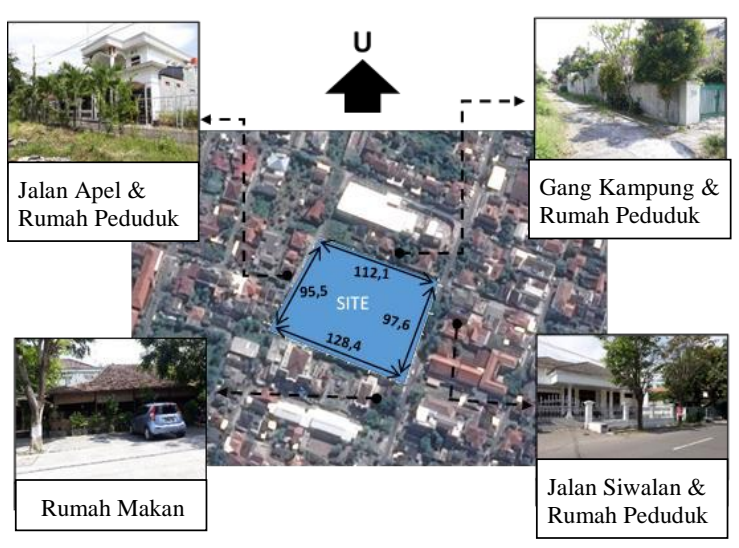

Gambar 1. Kondisi Eksisting Tapak Terpilih

\subsection{Persoalan Pengolahan Tapak}

Analisis pengolahan tapak terdiri dari analisis pencapaian, analisis kebisingan, serta analisis matahari dan angin yang akan menghasikan zona peruangan pada bangunan Pusat Pelayanan Lanjut Usia ini. 
Analisis pencapaian bertujuan untuk menentukan main entrance (ME) sebagai pintu masuk utama menuju ke dalam tapak dan side entrance (SE) sebagai pintu masuk untuk keperluan service (lihat Gambar 2). Dalam penentuan pencapaian, pendekatan psikologis digunakan karena mengutamakan kemudahan aksesibiitas menuju ke dalam tapak dan menghindari kesan crowded di sekitar tapak.

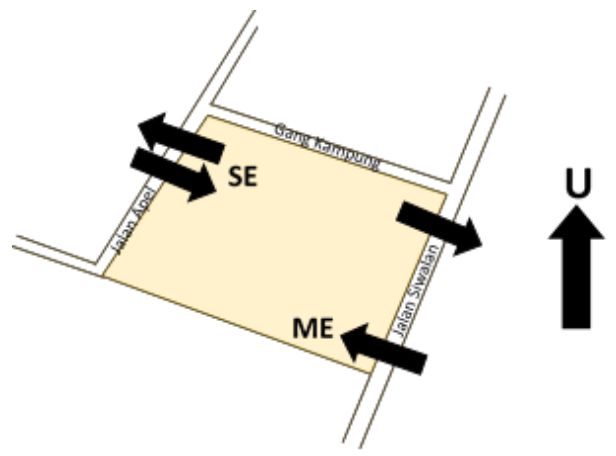

Gambar 2. Analisis Peletakan Main Entrance dan Side Entrance pada Tapak

Analisis kebisingan menjadi pertimbangan dalam peletakan zona berdasar kebutuhan ketenangan pada tiap area ruang. Intensitas kebisingan pada tiap sisi tapak dapat dilihat pada Gambar 3. Pendekatan indera pendengaran digunakan untuk mengetahui intensitas kebisingan pada tiap sisi tapak sehingga dapat menentukan respon untuk mengatasi kebisingan yang terlalu tinggi.

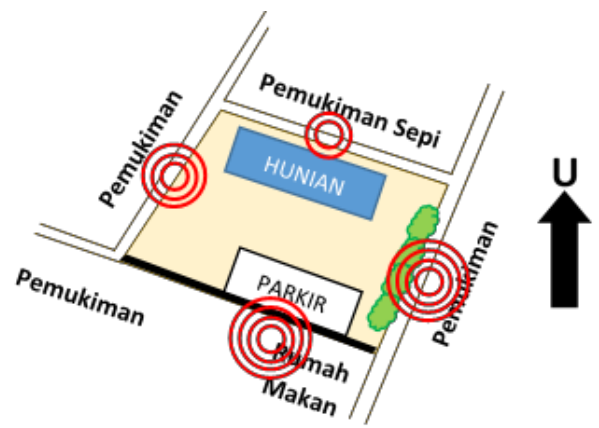

Gambar 3. Analisis Intensitas Kebisingan pada Tapak

Analisis matahari dan angin akan berkaitan dengan penentuan orientasi bangunan juga kebutuhan bukaan sebagai pencahayaan dan penghawaan alami. Arah lintasan matahari dan arah angin pada tapak dapat dilihat pada Gambar 4. Pendekatan indera penglihatan dan peraba akan berpengaruh pada analisis ini karena akan berpengaruh pada respon untuk mengatasi cahaya matahari dan angin yang berlebihan yang dapat berpengaruh pada tampilan dan material bangunan.

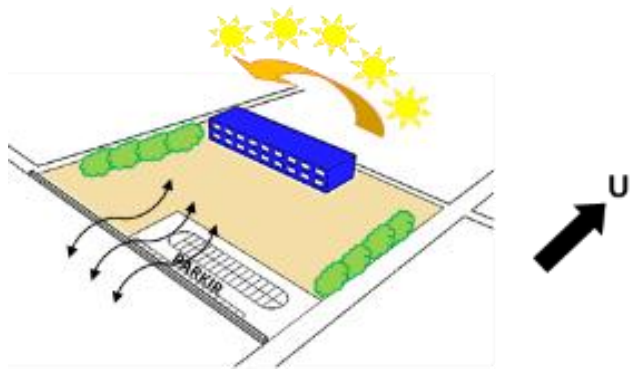

Gambar 4. Analisis Matahari dan Arah Angin yang Berpengaruh pada Orientasi Banguanan pada Tapak

\subsection{Persoalan Bentuk dan Tampilan}

\section{a. Eksterior}

Pendekatan indera penglihatan, indera peraba, dan pendekatan psikologi digunakan dalam pengolahan tampilan eksterior bangunan. Tampilan eksterior bangunan dipengaruhi juga oleh respon bangunan terhadap iklim di sekitar lingkungan yakni cahaya matahari, hembusan angin, dan hujan.

Pendekatan indera penglihatan dapat dilakukan dengan pengolahan bentuk dan tata massa bangunan. Bentuk dasar pada fasad adalah persegi panjang yang dipilih guna efisiensi ruang dan ditambah bentuk lengkung untuk memberi kedinamisan pada fasad. Pendekatan indera penglihatan dapat diterapkan juga dalam pemilihan warna. Pemilihan warna dipilih waran putih dengan kesan netral dan diberi aksen earna coklat mengikuti warna batu alam dan kisi-kisi kayu yang ada (lihat Gambar 5).

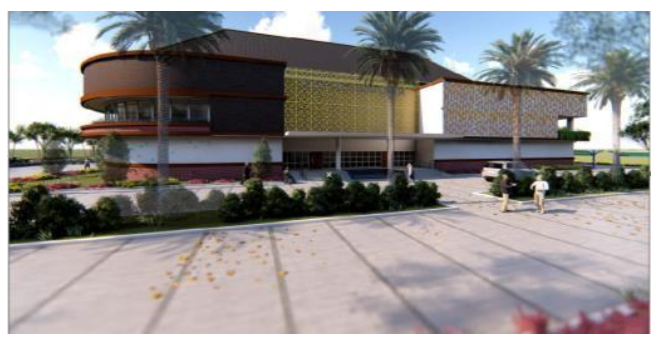

Gambar 5. Penerapan Pendekatan Healing Environment Berupa Pemilihan Warna dan Material pada Fasad Bangunan

Pendekatan indera peraba diterapkan dalam pemilihan material dan tekstur yang berbeda 
seperti batu alam, kisi kayu, batu bata ekspos sehingga tidak menampilkan kesan monoton.

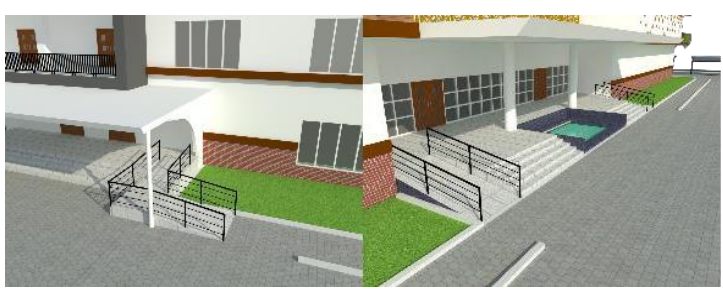

Gambar 6. Ramp Sebagai Aksesibilitas bagi Pengguna Kursi Roda

Pendekatan psikologis yang dapat diterapkan adalah pada penataan tampilan bangunan yang dibuat sederhana dan sesuai untuk laisia serta faktor keamanan bagi lansia yang diterapkan pada eksterior bangunan. Keamanan bagi lansia merupakan hal yang penting, sehingga diperlukan pelengkap seperti ramp yang dapat memudahkan aksesibilitas bagi lansia pengguna kursi roda. Ramp didesain dengan handrail sebagai pengaman, material lantai cor beton yang tidak licin, dan dengan kemiringan tidak lebih dari $7^{\circ}$ sesuai standar sehingga tidak terlalu curam (lihat Gambar 6).

\section{b. Healing Garden}

Healing garden menjadi unsur penting untuk mendukung konsep healing environment. Ruang terbuka ini dirancang dengan tujuan untuk dapat membantu memulihkan kondisi psikologis lanjut usia di pusat pelayanan ini. Tujuan healing garden adalah untuk membuat orang merasa aman, stres berkurang, lebih nyaman, dan merasa segar (Bihastuti dkk, 2017). Selain itu, healing garden dapat menjadi estetika dan sebagai barrier untuk mengurangi angin dan matahari yang terlalu banyak masuk ke dalam bangunan. Pendekatan alam akan diterapkan dalam healing garden ini dengan memasukkan unsur-unsur alam atau softscape landscape seperti rerumputan, tumbuhan herbal, pohon peneduh, dan lainlain. Pendekatan indera peraba diterapkan dalam pemilihan material dan tekstur pada hardscape landscape, serta pendekatan psikologis yang memberi ketenangan dan memulihkan kondisi psikologis lansia. Penerapan healing garden sebagai pendekatan alam dapat dilihat di Gambar 7.

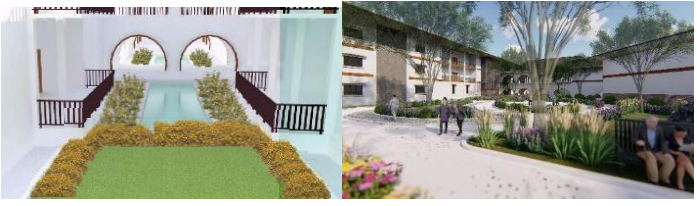

Gambar 7. Healing Garden sebagai Pendekatan Alam

\section{c. Interior}

Pada pengolahan elemen interior, seluruh pendekatan mempunyai alih bagian. Pendekatan indera penglihatan, peraba, pendengaran, dan penciuman memiliki peranan penting dalam elemen interior. Didukung dengan pendekatan alam berupa menambahakan unsur alam ke dalam bangunan sehingga memperkuat konsep healing environment. Pendekatan Psikologis juga mempunyai peran dalam menciptakan suasana yang nyaman, aman, dan memenuhi kebutuhan kelengkapan bagi lanjut usia.

Pada interior ruang tidur yang merupakan ruang yang paling sering digunakan oleh pengguna dalam bangunan ini, harus dirancang senyaman mungkin untuk beristirahat. Pada pusat pelayanan lanjut usia ini terdapat 3 tipe kamar, yakni kamar intensif yang ditujukan untuk pasien yang sakit dan sudah mengalami banyak penurunan fisik, kamar isi 2, dan kamar isi 4 dengan interior yang dapat dilihat pada Gambar 8.

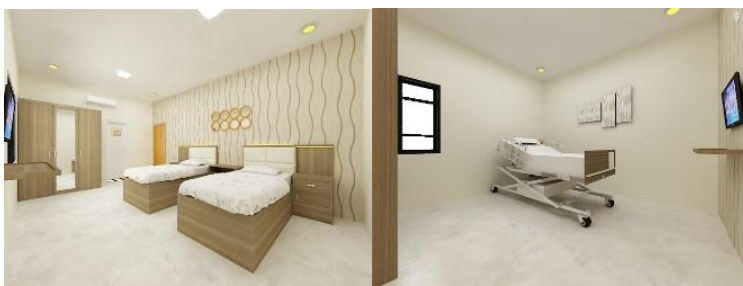

Gambar 8. Penerapan Pendekatan Healing Environment berupa Pemilihan Warna dan Handrail pada Interior Kamar Tidur

Warna yang dipilih pada dinding adalah warna krem dengan aksen wallpaper berwarna senada pula. Layout ruang dibuat sederhana dan tidak terlalu banyak furniture untuk mempermudah aksesibilitas lansia. Terdapat handrail pada dinding kamar sebagai pengaman dan pegangan bagi lansia. Khusus untuk kamar intensif ranjang yang digunakan adalah ranjang khusus mengingat lansia yang menggunakan kamar ini 
Koridor merupakan penghubung dari satu ruang menuju ruang yang lain. Koridor pada Pusat Pelayanan Lanjut Usia dirancang agar aman dan mudah dilewati oleh lansia baik lansia yang masih sehat, lansia yang sudah susah berjalan, maupun lansia dengan kursi roda.

Koridor pada area hunian ini memiliki lebar 2,8 meter dengan dilengkapi handrail sebagai pengaman dan pegangan bagi lansia lihat pada Gambar 9. Pola lantai dibuat berbeda untuk menunjukkan pintu masuk menuju kamar sehingga memudahkan lansia menemukan kamarnya. Pada bagian depan kamar terdapat papan yang menunjukkan nama penghuni dalam kamar sehingga memudahkan dalam pengawasan.

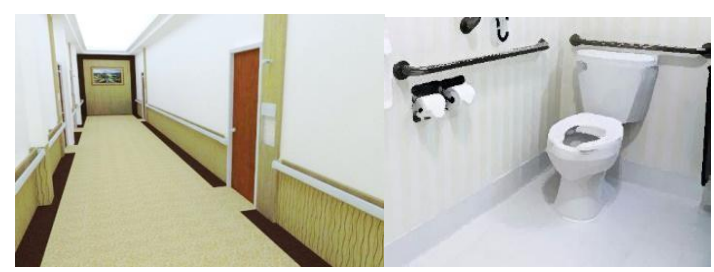

Gambar 9. Handrail sebagai Pengaman dan Pegangan pada Interior Koridor dan kamar mandi

Kemudian, kamar mandi didesain mengutamakan keamanan lansia dimana dipilih kloset duduk untuk mempermudah lansia dan dengan handrail sebagai pengaman dan pegangan dilihat pada Gambar 9. Material lantai dipilih material keramik unpolished sehingga tida licin dan memperkecil kemungkinan terpeleset.

\subsection{Hasil Akhir}

Pusat Pelayanan Lanjut Usia merupakan wadah dimana menyediakan pelayanan bagi lanjut usia berupa pelayanan hunian, pelayanan kesehatan, serta pelayanan pembinaan dengan menerapkan konsep healing environment untuk dapat menciptakan lingkungan yang kondusif sehingga dapat memperbaiki kondisi fisik maupun psikis lansia dengan rincian sebagai berikut (lihat Gambar 10, 11) :

Nama $\quad \begin{aligned} & \text { Pusat Pelayanan Lanjut Usia } \\ & \text { dengan Pendekatan Healing } \\ & \text { Environment di Surakarta }\end{aligned}$
Lokasi : $\begin{aligned} & \text { Jalan Siwalan, Kerten. } \\ & \text { Surakarta }\end{aligned}$

$$
\begin{array}{lll}
\text { Luas } & : & \pm 11.569 \mathrm{~m}^{2} \\
\text { Lahan } & & \\
\text { Kegiatan } & : \begin{array}{l}
\text { Hunian, Pelayanan, Periksa } \\
\text { Kesehatan, Administrasi, dan } \\
\end{array} \\
& \text { Kunjungan }
\end{array}
$$

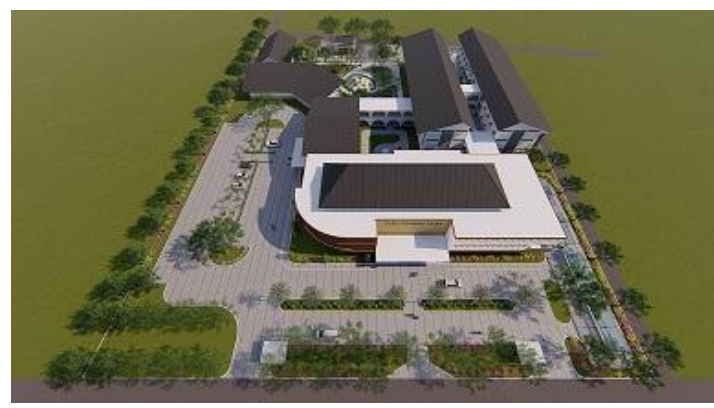

Gambar 10. Perspektif Pelayanan Lanjut Usia

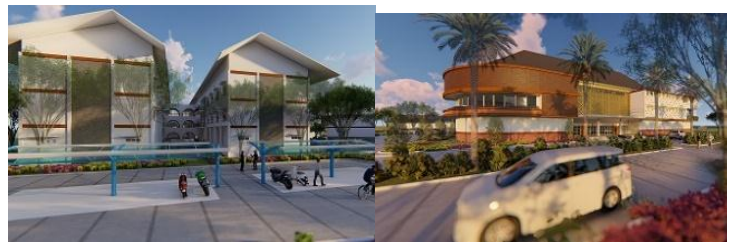

Gambar 11. Perspektif Eksterior Bangunan Pusat Pelayanan Lanjut Usia

\section{KESIMPULAN}

Konsep healing environment merupakan pilihan tepat dalam perancangan Pusat Pelayanan Lanjut Usia untuk mencapai lingkungan yang mendukung proses pemulihan kondisi fisik dan psikis dari lanjut usia. Strategi desain yang digunakan dalam perancangan Pusat Pelayanan Lanjut Usia ini adalah dengan menerapkan pendekatanpendekatan pada persoalan desain bangunan guna mencapai konsep healing environment.

Penerapan healing environment pada bangunan dilakukan dengan beberapa pendekatan, antara lain pendekatan indera yang dapat berupa pendekatan indera penglihatan, pendengaraan, peraba, dan penciuman. Pendekatan indera penglihatan dilakukan dengan pemilihan warna yang cocok pada ruang dan kondisinya. Pendekatan indera pendengaran dapat dilakukan dengan penanganan kebisingan dan penambahan efek suara baik secara alami maupun buatan yang dapat merelaksasi pengguna. Pendekatan indera peraba dilakukan dengan pemilihan 
material dan tekstur tertentu yang dapat menstimulasi pengguna sekaligus aman bagi pengguna. Sedangkan pendekatan indera penciuman dapat dilakukan penanganan bau tidak sedap dan penambahan aromatheraphy pada ruang untuk merelaksasi pengguna.

Kemudian pendekatan alam pada bangunan Pusat Pelayanan Lanjut Usia dapat dilakukan dengan memasukkan unsur alam ke dalam bangunan, seperti dengan pemberian bukaan pada ruang-ruang tertentu untuk memberikan pencahayaan dan penghawaan alami, juga sebagai view dalam bangunan. Selain itu pendekatan alam dapat pula dilakukan dengan penataan landscape di sekitar kawasan bangunan dan pemberian healing garden sebagai ruang terbuka yang dapat dimanfaatkan bagi pengguna untuk memulihkan kondisi fisik dan psikis pengguna.

Selanjutnya, pendekatan psikologis dapat dilakukan dengan menciptakan ligkungan yang dapat membuat pengguna merasa nyaman, aman, dan dapat beradaptasi dengan lingkungan serta disesuaikan standar khusus bagi lansia.

Penerapan pendekatan healing environment pada perancangan Pusat Pelayanan Lanjut Usia ini bertujuan untuk mewujudkan wadah pemenuhan hak-hak lansia untuk menikmati hari tuanya secara baik dengan kondisi lingkungan bangunan yang menunjang proses pemulihan dan perbaikan kondisi fisik dan psikis bagi lansia.

\section{REFERENSI}

Badan Pusat Statistik Indonesia. Statistik Penduduk Lanjut Usia Tahun 2016 (2017). Indonesia.

Bihastuti, E. J., Ummul Mustaqimah, \& Maya Andria Nirawati. (2017). PENERAPAN HEALING ENVIRONMENT PADA PERANCANGAN SEKOLAH DASAR LUAR BIASA BAGIAN TUNALARAS. Arsitektura Universitas Sebelas Maret,15.

Dijkstra, Karin. (2009). Understanding Healing Environments: Effects of Physical Environmental Stimuli on Patients' Health and Well-being. University of Twente, Enschede.
Kurniawati, Febriani. (2011). Peran Healing Environment Terhadap Proses Penyembuhan. Universitas Gajah Mada, Yogyakarta.

Lidyana, Vidra dkk. (2013). Konsep dan Aplikasi Healing Environment dalam Fasilitas Rumah Sakit. Universitas Tanjungpura, Pontianak.

Maryam, R. dkk. (2008). Mengenal Usia Lanjut dan Perawatannya. Jakarta : Salemba Medika.

Stamenovic, Ruzica Bozovic. (2009). Healing Spaces for Elderly. National University of Singapore, Singapore.

Stoneham, Jane dan Thoday. (1996). Landscape Design for Elderly and Disabled People. Woodbridge: Garden Art Press.

Zhafran, D. B., Hardiyati, \& Leny Pramesti. (2017). BALAI KESEHATAN JIWA DENGAN PENDEKATAN HEALING ENVIRONMENT DI SURAKARTA. Arsitektura Universitas Sebelas Maret, 15. 